\section{Economic burden of physical inactivity in hospitalizations due to dementia: a Brazilian nationwide study}

\author{
Carga econômica da inatividade física nas \\ internações hospitalares por demência: um \\ estudo de abrangência nacional no Brasil
}

\author{
Carga económica de la inactividad física en \\ hospitalizaciones por demencia: un estudio \\ de ámbito nacional en Brasil
}

\begin{abstract}
Our study aimed at determining the economic burden of leisure-time physical inactivity in hospitalizations due to dementia in Brazil. In this national-wide descriptive study, we used secondary data from the Brazilian Health Informatics Department and from the latest Brazilian National Health Survey (2013). Rate of hospitalization and economic cost were extracted from 2013. Leisure-time physical inactivity prevalence was used to estimate its population attributable fraction for dementia. Outcomes were stratified into sex (man/ woman), age groups (<50, 50-59, 60-69, 70-79, 80+), ethnicity (white, black, mixed race, other), and region (South, Southeast, North, Northeast, and Central). In 2013, 3,724 people were hospitalized due to dementia in Brazil resulting in a total cost of BRL 17,971,833.85 (USD 7,673,973.05). More than half of cost among men was spent with individuals younger than 59 years, white and mixed-race, and from Southeast region. Proportion of cost was higher in women older than 60 years and white. In 2013, 37\% of all hospitalization from dementia in Brazil were attributable to physical inactivity, with values reaching $42.9 \%$ and $43.8 \%$ for men and women aged 80 or older, respectively. Physical inactivity cost BRL 6,994,254.75 (USD 2,986,546.78) in 2013 on hospitalizations due to dementia in Brazil. Higher attributable-cost was found for patients younger than 50 years and women older than 80. Strategies to preserve the quality of life of these patients are needed to reduce the burden for the patients, their family, and on the healthcare system.
\end{abstract}

Demetia; Exercise; Hospitalization
Natan Feter 1,2

Jayne Santos Leite 1

Rodrigo Kohn Cardoso 3

Airton José Rombaldi 1

doi: 10.1590/0102-311X00046520

\author{
Correspondence \\ N. Feter \\ Rua Luís de Camões 625, Pelotas, RS 96055-630, Brasil. \\ natanfeter@hotmail.com \\ 1 Universidade Federal de Pelotas, Pelotas, Brasil. \\ 2 The University of Queensland, St. Lucia, Australia. \\ 3 Colégio Militar de Porto Alegre, Porto Alegre, Brasil.
}




\section{Introduction}

Dementia is a chronic and degenerative syndrome that affected around 50 million people in 20191. Population growth, ageing, and increased prevalence of dementia-related risk factors lead Brazil to the second highest age-standardized prevalence of dementia in the world, affecting about 1.7 million people 2 . Whereas the number of deaths attributable to dementia decreased in the last 10 years in some Latin American countries 2 , the mortality rate from this disease increased annually about $12 \%$ in men and 13\% in women in Brazil from 2000 to 20083.

Moreover, patients with dementia have higher prevalence of comorbidities compared to cognitively healthy older people 4 . Besides leading to increased rate of hospitalization 5 , the treatment of those comorbidities is more complex 6 , expensive 7 , and unequal 4 in patients suffering dementia, resulting in longer and more costly hospital admissions 4 . Consequently, longer hospitalizations are linked to higher incidence of cognitive decline that may become irreversible if treated incorrectly 8,9 .

The total individual cost per year of patients with dementia in Brazil is greater than the global average in all disease stages 10. In 2016, only $34 \%$ of total health financing in Brazil was spent by the government. However, more than $65 \%$ of hospitalizations due to dementia were covered by the Brazilian public healthcare system (Brazilian Health Informatics Department - DATASUS. http://www2. datasus.gov.br/DATASUS/index.php, accessed on Mar/2020). In addition, around 50\% of people living with dementia in Brazil have another chronic condition 10. Those facts show the recent past, current, and future social and economic burden of dementia in Brazil.

Although ageing is the strongest risk factor for dementia 11 , more than $50 \%$ of all its cases in low- and middle-income countries (accounting for about $70 \%$ of all dementia cases in the world 12 ) could be attributable to the following modifiable risk factors: smoking, diabetes, obesity, hypertension, depression, low schooling, hearing loss, social isolation and physical inactivity ${ }^{13}$. Indeed, a $20 \%$ reduction in the prevalence of those risk factors would lead to a reduction of $18.1 \%$ in the prevalence of dementia in Brazil by 205014.

Despite being associated with lower risk of cognitive decline in later life 15,16, the prevalence of regular leisure-time physical activity did not increase between 2000 and 2015 in any region of the world 17 . Physical inactivity is characterized in adults as do not achieve at least 150 minutes of moderate-intensity aerobic physical activity per week, or 75 minutes of vigorous-intensity aerobic physical activity per week, or an equivalent combination of both 18 . Although physical inactivity among older people was associated with poor cognitive function 15, high level of dependency 19, and increased allcause mortality risk 20, its prevalence is still high among older adults in Brazil 21.

Bielemann et al. 22 reported that $14 \%$ of cost from hospitalizations due to diabetes, some types of cancer, cardiovascular diseases, and osteoporosis in Brazil were linked to physical inactivity; however, there is no data about its impact on dementia-related hospital admission. Then, we aimed to determine the economic burden of leisure-time physical inactivity in hospitalizations due to dementia in Brazil.

\section{Method}

To conduct this national-wide descriptive study, we used secondary data from the Hospital Information Systems of the Brazilian Unified National Health System (SIH/SUS, in Portuguese) (DATASUS. http://www2.datasus.gov.br/DATASUS/index.php, accessed on Mar/2020) and from the latest Brazilian National Health Survey (PNS, in Portuguese) 23. PNS was approved by The National Commission of Ethics in Research (Regulation n. 328,159) 23. DATASUS is an open-access non-nominal database, so no ethical approval is needed to extract data from this database.

Nationalwide data about hospitalization and total economic cost from these hospitalizations in Brazil during 2013 were extracted from SIH/SUS. We selected 2013 because it was the latest year with population-based data about physical activity in Brazil measured by validated instrument (International Physical Activity Questionnaire - IPAQ) 24. Number and cost of hospitalizations was extracted from DATASUS (http://www2.datasus.gov.br/DATASUS/index.php, accessed on Mar/2020). Total hospitalizations were considered as all new authorized hospitalization forms, transferences, and re- 
hospitalizations related to dementia. Total economic cost was considered as the value referred to all services to all hospitalizations throughout a specific period (2013). When applicable, we converted Brazilian Real (BRL) to US Dollar (USD) based on conversion rate in data registration year (December 31th, 2013): BRL $1.00=$ USD 0.427.

The cause of hospitalizations was informed as the main diagnose that motived them. For dementia, we considered all hospitalizations from which the main diagnose was defined as dementia in Alzheimer's disease (ICD-10: F00; G30), vascular dementia (ICD-10: F01), dementia in other disease classified elsewhere (ICD-10: F02), and unspecified dementia (ICD-10: F03), according to International Classification of Diseases, 10th revision (ICD-10) 24. We also stratified these outcomes based on sex (man/woman), age groups (less than 50 years, 50-59, 60-69, 70-79, 80 or older), ethnicity (white, black, mixed race, other - yellow, indigenous, and unknown), and region (South, Southeast, North, Northeast, and Central). Age was estimated based on date of birth and date of admission.

Rate of hospitalization was determined by dividing the number of hospitalizations by the total population and from each group (sex, ethnicity, and region). Data about total population in 2013 was extracted from Brazilian Institute of Geography and Statistics (IBGE, in Portuguese) 25.

To determine the economic burden of physical inactivity in hospitalizations due to dementia, we calculated the population attributable fraction (PAF) for this exposure. We used the formula below based on previous publication 13,22,26. The PAF aims at identifying the percental reduction in the prevalence of certain disease or health condition (e.g. hospitalization due to dementia) if certain risk factor (e.g. physical inactivity) was eliminated.

$$
P A F=\frac{p^{*}(R R-1)}{p^{*}(R R-1)+1}
$$

Where, p: prevalence of physical inactivity and RR: relative risk.

We used the RR calculated by Hamer \& Chida 27 in a meta-analysis with a sample of 23,168 participants from different countries (Finland, United States, China, Sweden, Canada, and France). The study identified that physical inactivity was associated with a RR of 1.82 (95\%CI: $1.19 ; 2.78)$ for dementia. All included studies reported adjusted RR by covariates such as age, gender, and education level.

Self-reported physical activity behavior was extracted from PNS. This cross-sectional populationbased survey was to date the most complete health survey already conducted in Brazil. It covered data about sociodemographic, health status, behavior, and healthcare utilization among Brazilian adult population (i.e. aged 18 or older). Due to its three-stage probabilistic sampling and use of weighted estimates, the information from PNS can be extrapolated to all Brazilian adult population 23. From 81,167 households included in the PNS, 60,202 individuals completed interviews about lifestyle and health status (response rate: 74.2\%). As mentioned earlier, physical activity was measured by the IPAQ, which includes questions on frequency and duration of physical activity in leisure-time. A final score was generated from multiplying the weekly frequency of physical activity by its duration in minutes. Participants that did not achieved at least 150 minutes of moderate physical activity or 75 minutes of vigorous physical activity or an equivalent combination of moderate and vigorous activity per week in leisure time were classified as physically inactive 18 .

At descriptive analysis, hospitalization rate, total economic cost, physical inactivity prevalence, and PAF for this risk factor were stratified by sex (man, woman), age groups (< 50 years, 50-59, 60-69, 70-79, and 80+), ethnicity, (white, black, mixed race, other), and country region (Central, North, Northeast, South, Southeast). Data were imported into Stata 13.1 (https://www.stata.com/) and were reported in absolute and relative values. 


\section{Results}

In 2013, 3,724 people were hospitalized due to dementia in Brazil. Among men, $61.2 \%$ of admissions were of adults aged 69 years or less and $61.5 \%$ in Southeast region. Most of hospitalizations from dementia in women occurred in patients older than 70 years (55.2\%), white (44.2\%), and from Southeast region (64\%) (data not shown). Table 1 shows that, although the rate of hospitalizations increases with ageing, men had higher values before aged 80 compared to women.

In Brazil, the total cost of hospitalization from dementia in 2013 was BRL 17,971,833.85 (USD $7,673,973.05)$. More than half of cost among men were spent with individuals younger than 59 years (54.6\%), white and mixed (51.5\%), and from Southeast region (87.9\%). Women and men had similar distribution among regions, but the proportion of cost was higher in patients older than 60 years (57.8\%) and white (53.7\%).

In 2013, 77.7\% of Brazilian population were physically inactive during leisure time with higher prevalence among women (Table 2). Men aged less than 50 years had lower prevalence of physical inactivity compared to other male and to female age groups. Men and women aged 70 or older were more physically inactive compared to any younger group from the same sex. Women were more inactive than men regardless of ethnicity and region.

About $37 \%$ of all hospitalization from dementia in Brazil were attributable to physical inactivity in 2013 , with values reaching $42.9 \%$ and $43.8 \%$ for men and women aged 80 or older, respectively, and $41 \%$ and $40.8 \%$ for black women and in North region, respectively.

Table 3 shows that the economic burden of physical inactivity in hospitalizations due to dementia was estimated in BRL 6,994,254.75 (USD 2,986,546.78). White patients and at Southeast region had higher cost attributable to physical inactivity regardless of sex. While physical inactive accounts for greater cost among men younger than 50 years, we observed that this exposure has higher impact in hospitalizations of women aged less than 50 and older than 80 years.

Table 1

Total hospital admissions and inpatient cost due to dementia. Brazil, $2013(n=3,724)$.

\begin{tabular}{|c|c|c|c|c|c|c|}
\hline & \multicolumn{3}{|c|}{$\begin{array}{l}\text { Rate of hospitalizations due to dementia in } 2013, \\
\text { per 100,000 inhabitants }\end{array}$} & \multicolumn{3}{|c|}{$\begin{array}{l}\text { Total cost of hospitalizations for dementia } \\
\text { [in million BRL (\%)] }\end{array}$} \\
\hline & Man & Woman & Total & Man & Woman & Total \\
\hline Total & 1.84 & 1.86 & 1.85 & $9.34(52.0)$ & $8.64(48.0)$ & $17.97(100.0)$ \\
\hline \multicolumn{7}{|c|}{ Age group (years) } \\
\hline$<50$ & 0.77 & 0.57 & 0.67 & $3.95(42.4)$ & $2.73(31.7)$ & $6.69(37.2)$ \\
\hline $50-59$ & 2.44 & 1.44 & 1.91 & $1.14(12.2)$ & $0.91(10.5)$ & $2.05(11.4)$ \\
\hline $60-69$ & 4.40 & 3.46 & 3.88 & $1.45(15.5)$ & $1.27(14.7)$ & $2.71(15.1)$ \\
\hline $70-79$ & 11.06 & 10.47 & 10.74 & $1.55(16.5)$ & $1.25(14.5)$ & $2.80(15.6)$ \\
\hline $80+$ & 28.80 & 34.46 & 32.26 & $1.25(13.4)$ & $2.47(28.6)$ & $3.72(20.7)$ \\
\hline \multicolumn{7}{|l|}{ Ethnicity } \\
\hline White & 2.11 & 2.11 & 2.11 & $3.86(41.3)$ & $4.63(53.7)$ & $8.49(47.3)$ \\
\hline Black & 0.96 & 1.31 & 1.14 & $0.95(10.2)$ & $0.90(10.4)$ & $1.85(10.3)$ \\
\hline Mixed race & 0.74 & 0.64 & 0.69 & $3.24(34.8)$ & $2.14(24.8)$ & $5.38(29.9)$ \\
\hline Other & 42.11 & 39.18 & 40.32 & $1.28(13.8)$ & $0.96(11.2)$ & $2.25(12.5)$ \\
\hline \multicolumn{7}{|l|}{ Region } \\
\hline North & 0.41 & 0.25 & 0.19 & $0.01(0.1)$ & $0.01(0.1)$ & $0.02(0.1)$ \\
\hline Northeast & 0.43 & 0.33 & 0.48 & $0.53(5.7)$ & $0.26(3.0)$ & $0.79(4.4)$ \\
\hline Southeast & 2.72 & 2.82 & 2.04 & $8.21(87.9)$ & $7.67(88.8)$ & $15.88(88.4)$ \\
\hline South & 3.30 & 3.26 & 2.11 & $0.48(5.2)$ & $0.45(5.2)$ & $0.93(5.2)$ \\
\hline Central & 1.08 & 1.22 & 1.19 & $0.10(1.1)$ & $0.24(2.8)$ & 0.35 (1.9) \\
\hline
\end{tabular}




\section{Table 2}

Prevalence of physical inactivity and hospitalizations due to dementia attributable to physical inactivity.

Brazil, $2013(n=60,202)$.

\begin{tabular}{|c|c|c|c|c|}
\hline & \multicolumn{2}{|c|}{$\begin{array}{l}\text { Prevalence of physical inactivity } \\
{[\%(95 \% \mathrm{Cl})]}\end{array}$} & \multicolumn{2}{|c|}{$\begin{array}{l}\text { Population attributable fraction } \\
\qquad[\%(95 \% \mathrm{Cl})]\end{array}$} \\
\hline & Man & Woman & Man & Woman \\
\hline Total & $72.3(71.7 ; 72.8)$ & $81.9(81.5 ; 82.3)$ & $37.2(12.1 ; 56.3)$ & $40.2(13.5 ; 59.3)$ \\
\hline \multicolumn{5}{|c|}{ Age group (years) } \\
\hline$<50$ & $66.5(65.8 ; 67.2)$ & $80.6(80.1 ; 81.1)$ & $35.3(11.2 ; 54.2)$ & $39.8(13.3 ; 58.9)$ \\
\hline $50-59$ & $81.9(80.7 ; 83.0)$ & $82.5(81.4 ; 83.5)$ & $40.2(13.5 ; 59.3)$ & $40.3(13.5 ; 59.5)$ \\
\hline $60-69$ & $84.1(82.6 ; 85.4)$ & $82.2(80.9 ; 83.4)$ & $40.8(13.8 ; 59.9)$ & $40.3(13.5 ; 59.4)$ \\
\hline $70-79$ & $87.0(85.1 ; 88.6)$ & $88.2(86.7 ; 89.6)$ & $41.6(14.2 ; 60.8)$ & $42.0(14.4 ; 61.1)$ \\
\hline $80+$ & $91.5(88.8 ; 93.6)$ & $94.9(93.3 ; 96.1)$ & $42.9(14.8 ; 62.0)$ & $43.8(15.3 ; 62.8)$ \\
\hline \multicolumn{5}{|l|}{ Ethnicity } \\
\hline White & $71.0(70.1 ; 71.9)$ & $79.1(78.4 ; 79.8)$ & $36.8(11.9 ; 55.8)$ & $39.3(13.1 ; 58.5)$ \\
\hline Black & $73.3(71.6 ; 75.0)$ & $84.7(83.4 ; 85.9)$ & $37.6(12.2 ; 56.6)$ & $41.0(13.9 ; 60.1)$ \\
\hline Mixed race & $73.2(72.4 ; 73.9)$ & $83.7(83.1 ; 84.2)$ & $37.5(12.2 ; 56.6)$ & $40.7(13.7 ; 59.8)$ \\
\hline Other & $68.8(63.9 ; 73.3)$ & $81.0(77.6 ; 84.0)$ & $33.1(11.6 ; 55.1)$ & $39.9(13.3 ; 59.0)$ \\
\hline \multicolumn{5}{|l|}{ Region } \\
\hline North & $71.6(70.4 ; 72.7)$ & $84.2(83.3 ; 85.0)$ & $37.0(12.0 ; 56.0)$ & $40.8(13.8 ; 60.0)$ \\
\hline Northeast & $73.5(72.5 ; 74.4)$ & $83.1(82.3 ; 83.8)$ & $37.6(12.2 ; 56.7)$ & $40.5(13.6 ; 59.7)$ \\
\hline Southeast & $72.7(71.6 ; 73.8)$ & $80.2(78.9 ; 81.3)$ & $37.4(12.1 ; 56.4)$ & $39.9(13.3 ; 59.1)$ \\
\hline South & $71.3(69.8 ; 72.9)$ & $80.2(78.9 ; 81.3)$ & $36.9(11.9 ; 55.9)$ & $39.7(13.2 ; 58.8)$ \\
\hline Central & $70.7(69.1 ; 72.2)$ & 78.5 (77.3; 79.8) & $36.7(11.8 ; 55.7)$ & $39.2(13.0 ; 58.3)$ \\
\hline
\end{tabular}

\section{Table 3}

Economic cost of hospitalizations due to dementia attributable to physical inactivity. Brazil, $2013(n=3,724)$.

\begin{tabular}{|c|c|c|c|}
\hline & \multicolumn{3}{|c|}{$\begin{array}{l}\text { Cost of hospitalizations for dementia attributable to physical inactivity } \\
\qquad \text { [in million BRL }(95 \% \mathrm{Cl})]\end{array}$} \\
\hline & Man & Woman & Total \\
\hline Total & $3.47(1.13 ; 5.25)$ & $3.47(1.16 ; 5.12)$ & $6.99(2.31 ; 10.45)$ \\
\hline \multicolumn{4}{|c|}{ Age group (years) } \\
\hline$<50$ & $1.40(0.44 ; 2.15)$ & $1.09(0.36 ; 1.61)$ & $2.54(0.83 ; 3.82)$ \\
\hline $50-59$ & $0.46(0.15 ; 0.68)$ & $0.37(0.12 ; 0.54)$ & $0.82(0.28 ; 1.22)$ \\
\hline $60-69$ & $0.59(0.20 ; 0.87)$ & $0.51(0.17 ; 0.75)$ & $1.10(0.37 ; 1.62)$ \\
\hline $70-79$ & $0.64(0.22 ; 0.94)$ & $0.53(0.18 ; 0.77)$ & $1.17(0.40 ; 1.71)$ \\
\hline $80+$ & $0.53(0.18 ; 0.77)$ & $1.08(0.38 ; 1.55)$ & $1.62(0.56 ; 2.33)$ \\
\hline \multicolumn{4}{|l|}{ Ethnicity } \\
\hline White & $1.42(0.46 ; 2.15)$ & $1.82(0.61 ; 2.71)$ & $3.25(1.07 ; 4.89)$ \\
\hline Black & $0.36(0.12 ; 0.54)$ & $0.37(0.12 ; 0.54)$ & $0.73(0.24 ; 1.09)$ \\
\hline Mixed & $1.22(0.40 ; 1.84)$ & $0.87(0.29 ; 1.28)$ & $2.12(0.70 ; 3.15)$ \\
\hline Other & $0.46(0.15 ; 0.71)$ & $0.38(0.13 ; 0.57)$ & $0.86(0.28 ; 1.30)$ \\
\hline \multicolumn{4}{|l|}{ Region } \\
\hline North & $0.004(0.001 ; 0.006)$ & $0.004(0.001 ; 0.006)$ & $0.008(0.003 ; 0.012)$ \\
\hline Northeast & $0.20(0.06 ; 0.30)$ & $0.11(0.04 ; 0.16)$ & $0.31(0.10 ; 0.46)$ \\
\hline Southeast & $3.07(1.00 ; 4.63)$ & $3.06(1.02 ; 4.53)$ & $6.17(2.04 ; 9.23)$ \\
\hline South & $0.18(0.06 ; 0.27)$ & $0.18(0.06 ; 0.26)$ & $0.36(0.12 ; 0.54)$ \\
\hline Central & $0.04(0.01 ; 0.06)$ & $0.10(0.03 ; 0.14)$ & $0.13(0.04 ; 0.20)$ \\
\hline
\end{tabular}




\section{Discussion}

Our study reported that 37\% from all 3,724 hospitalizations due to dementia at Brazil in 2013 was linked to physical inactivity resulting in an economic burden of BRL 6,994,254.75 (95\%CI: $2,311,879.12 ; 10,454,848.60)$. Besides, physical inactivity accounted for $43.5 \%$ of all dementia-related hospitalizations in patients aged 80 years or older. Also, women had more hospitalizations attributable to physical inactivity than men regardless of ethnicity and country's region.

The number of studies that evaluated the economic impact of physical inactivity in hospital admissions in Brazil is limited. Sichieri et al. 28 stated that physical inactivity was related to nearly $36 \%$ of all diabetes-related inpatient cost in adults aged between 20 and 60 years, values that are near what we reported for overall sample and for those aged up to 60 years (37\%). Bielemann et al. 22 reported that about $15 \%$ of all hospitalizations from diabetes, breast and colon neoplasm, cerebrovascular and ischemic heart disease, hypertension, and osteoporosis in 2013 were attributable to physical inactivity in Brazil, with the lowest patient fractions from South and Central regions. In our study, despite the different population attributable factor (37\%) for dementia, we found the lowest values at the same regions. Our results provide a novel perspective about how physical inactivity is associated with hospital admissions due to dementia in Brazil.

Bielemann et al. 22 exposed that all hospitalizations due to non-communicable chronic disease in Brazil accounted for USD 451,987,141.82 in 2013. From this value, USD 67,395,324.61 were attributable to physical inactivity. From 2000 to 2018, deaths from Alzheimer's disease-type dementia increase about $146.2 \%$ in United States, a percentage higher than stroke, heart disease, and breast or prostate cancer1. Likewise, data from SIH/SUS showed that the number and economic cost of hospitalizations due to dementia increased more than any of beforementioned chronic diseases from 2010 to 2017 in Brazil. Although this value found by Bielemann et al. 22 was higher than that found in our study, dementia has impacted the Brazilian healthcare system in last years; however, a larger effect is expected in the next years. Therefore, strategies to reduce this disease economic and social burden are need, especially in Brazil.

The prevalence of physical inactivity, which is linked to around $18 \%$ of all dementia cases in the world 29 is persistently high in Brazilian population especially in children, adolescentes 30 and older population 21. Women are more likely to develop dementia than men, especially in older ages 31 , what may explain the higher rate of hospitalization among women in patients aged 80 years or older. Based on our results, about $44 \%$ of hospitalizations from dementia in Brazil were linked to physical inactivity among women older than 80 years in 2017 . This population stratum is affected by loss of physical and cognitive capacity, which may act as important barriers to physical activity practice 32 . Thus, public policies need to be designed as ageing-friendly interventions to promote physical activity practice and maintenance during aging.

Moreover, men had higher rate of hospitalization than women among individuals aged 69 years or less. Likewise, the proportion of hospitalizations attributable to physical inactivity was higher among men aged between 60 and 69 years than women. Alzheimer's disease is the most prevalent type of dementia1, and vascular dementia appears as the second leading cause of this syndrome 33 . However, vascular dementia has higher incidence rate among men ${ }^{34}$. This difference may be explained by a worse cardiovascular health in men. Hypertensive 35 and cerebrovascular diseases 36 are common causes of vascular dementia and about $57 \%$ of all premature deaths that occurred among men between 30 and 69 years in Brazil in 2017 were due to those diseases (Brazilian Ministry of Health. http://svs. aids.gov.br/dantps/centrais-de-conteudos/paineis-de-monitoramento/mortalidade/dcnt/, accessed on Mar/2020). This picture exposes the "survival bias" in dementia prevalence: men that live longer may have better cardiovascular health, what lead to a decreased risk to develop some ageing-related illness such as Alzheimer's disease 37. Nevertheless, we still observed high rates of hospitalizations due to dementia in the oldest age group, what corroborated previous findings 1,6 and emphasized the need to promote low-cost strategies such as physical activity to reduce the burden of dementia in Brazilian health system.

Furthermore, whereas high hospitalization rates were found among women, we revealed that men reported higher economic costs from hospitalization due to dementia. One third of men in Brazil do not perform annual screenings (i.e. check-up) 38. Common imaging medical tests such echocardio- 
gram and ultrasonography could decrease the risk for cardiovascular events that are associated with dementia. Then, hospital admissions among men are more likely to be related to advanced stages of dementia, which requires more hospital services and then increased economic cost.

Although rates of hospitalizations were the highest among subjects with ignored ethnicity classification in SIH/SUS, we could observe that it was higher among white people than among black and mixed patients in both sexes. Also, though mixed-race patients had a rate of hospital admission $60 \%$ lower than black individuals, the inpatient economic cost was 2.9 times higher when compared with black patients. Despite other studies did not find a higher prevalence of dementia in this ethnic group 39,40, it was observed an increased inpatient burden of dementia among black individuals. Even though more than half of Brazilian population is declared non-white 25, the country is constantly facing a racial disparity. Whites have higher monthly income and schooling years than mixed subjects 25 . Likewise, non-whites are more likely to smoke, to have heavy episodic drinking, physical inactivity, sedentarism, and poor diet compared to white individuals 41 . Although the higher hospitalizations rates among white patients may be explained by higher life expectancy in this group 41 , our results indicate a racial disparity among economic cost of hospitalizations due to dementia.

Our study has important limitations. First, the SIH/SUS did not accurately provide the ethnicity group for all patients. Nevertheless, we could report some social disparity related to economic burden of dementia among mixed and white patients. Second, we reported that RR was generated using data from six different countries. However, five of them are classified as high-income countries, what could reduce the translation of this measure into the Brazilian healthcare system. However, as already mentioned by Mukadam et al. ${ }^{13}$, there are no meta-analyses that estimated the RR for dementia by physical inactivity using data exclusively from low-and middle-income countries. Moreover, extracting RR from meta-analysis instead of individual studies is a more precise and comparable method 42 .

Third, Levin's formula was designed to provide PAF using unadjusted RR. Here, the RR estimated by Hamer \& Chida 27 was adjusted for some important confoundings such age, sex, and educational level. However, the usage of other methods was not possible. For example, the PAF formula suggested by Miettinen et al. 43 requires the prevalence of the exposure (i.e. physical inactivity) among cases (i.e. hospitalized patients with dementia). Nevertheless, no nationalwide data about physical inactivity in dementia patients from Brazil is available.

Fourth, although physical activity could be measured in different domains such as work and during work/back home trip, we decided to determine physical inactivity only by leisure time for some reasons. Firstly, due to the greater potential for future interventions in this population 44 . Secondly, the lower prevalence of physical activity in commuting domain in individuals older than 40 years in Brazilian population 45 could overestimate our results. Thirdly, the articles included in the systematic review that generated the relative risk of physical inactivity for dementia 27 and other that used similar methodology 26,29 primarily used physical inactivity in leisure time to determine the impact of this risk factor in other chronic diseases such as dementia. Lastly, we presume that this classification may prevent overestimation of our findings, enable greater comparison with other populations, and illustrated the possible impact of leisure time physical activity promotion 13,46 .

Finally, we extracted data about hospitalizations due to dementia using the DATASUS. Although it is a federal open-access nationalwide database, there are some limitations that need to be acknowledged regarding its use. First, DATASUS comprehends data from hospitalizations covered by the Brazilian Unified National Health System - SUS (i.e. Brazilian public healthcare system). Consequently, information about hospitalization in private hospitals may be missing. However, besides the fact that two of three older adults in Brazil have no private health insurance 41, two thirds of hospitalizations due to dementia were covered by the Brazilian public healthcare system in 2013 (DATASUS. http:// www2.datasus.gov.br/DATASUS/index.php, accessed on Mar/2020). Second, DATASUS may have different levels of sub-notification across the country, which could underestimate our findings.

We conclude that $37 \%$ of economic cost from hospitalizations in Brazil due to dementia were attributable to physical inactivity in 2013, with the highest patient fractions occurring in older patients. These results enhance the perspective about the role of physical inactivity in burden of dementia and its impact on Brazilian healthcare system. Dementia is a chronic and progressive disorder with elevated economic and social cost. Therefore, strategies to preserve the quality of life of these patients are needed to reduce the burden for the patients, their family, and on healthcare system. 


\section{Contributors}

N. Feter, J. S. Leite, R. K. Cardoso and A. J. Rombaldi contributed equally to the drafting of the manuscript and made critical revisions thereof.

\section{Additional informations}

ORCID: Natan Feter (0000-0001-6295-9792); Jayne Santos Leite (0000-0002-4612-7301); Rodrigo Kohn Cardoso (0000-0002-0914-1251); Airton José Rombaldi (0000-0002-6707-814X).

\section{References}

1. 2020 Alzheimer's disease facts and figures. Alzheimers Dement 2020; 16:391-460.

2. GBD 2016 Dementia Collaborators. Global, regional, and national burden of Alzheimer's disease and other dementias, 1990-2016: a systematic analysis for the Global Burden of Disease Study 2016. Lancet Neurol 2019; 18:88106.

3. Teixeira JB, Souza Junior PRB, Higa J, Theme Filha MM. Mortality from Alzheimer's disease in Brazil, 2000-2009. Cad Saúde Publica 2015; 31:850-60.

4. Bunn F, Burn A-M, Goodman C, Rait G, Norton S, Robinson L, et al. Comorbidity and dementia: a scoping review of the literature. BMC Med 2014; 12:192.

5. Phelan EA, Borson S, Grothaus L, Balch S, Larson EB. Association of incident dementia with hospitalizations. JAMA 2012; 307:165-72.

6. Desai U, Kirson NY, Ye W, Mehta NR, Wen J, Andrews JS. Trends in health service use and potentially avoidable hospitalizations before Alzheimer's disease diagnosis: a matched, retrospective study of US Medicare beneficiaries. Alzheimers Dement (Amst) 2019; 11:125-35.

7. Hill JW, Futterman R, Duttagupta S, Mastey V, Lloyd JR, Fillit H. Alzheimer's disease and related dementias increase costs of comorbidities in managed Medicare. Neurology 2002; 58:62-70.

8. Covinsky KE, Palmer RM, Fortinsky RH, Counsell SR, Stewart AL, Kresevic D, et al. Loss of independence in activities of daily living in older adults hospitalized with medical illnesses: increased vulnerability with age. J Am Geriatr Soc 2003; 51:451-8.

9. Palleschi L, De Alfieri W, Salani B, Fimognari FL, Marsilii A, Pierantozzi A, et al. Functional recovery of elderly patients hospitalized in geriatric and general medicine units. The PROgetto DImissioni in GEriatria Study. J Am Geriatr Soc 2011; 59:193-9.

\section{Acknowledgments}

This work was supported by a partnership between Brazilian Graduate Studies Coordinating Board (CAPES), Federal University of Pelotas and the School of Human Movement and Nutrition Sciences, University of Queensland that enabled international collaborative work to be undertaken. $\mathrm{N}$. Feter was funded by a scholarship from CAPES. This study was financed in part by CAPES (Finance Code 001).

10. Ferretti C, Sarti FM, Nitrini R, Ferreira FF, Brucki SMD, et al. An assessment of direct and indirect costs of dementia in Brazil. PLoS One 2018; 13:e0193209.

11. Qiu C, De Ronchi D, Fratiglioni L. The epidemiology of the dementias: an update. Curr Opin Psychiatry 2007; 20:380-5.

12. Ferri CP, Jacob KS. Dementia in low-income and middle-income countries: different realities mandate tailored solutions. PLoS Med 2017; 14:e1002271.

13. Mukadam N, Sommerlad A, Huntley J, Livingston G. Population attributable fractions for risk factors for dementia in low-income and middle-income countries: an analysis using cross-sectional survey data. Lancet Glob Health 2019; 7:e596-603.

14. Oliveira D, Jun Otuyama L, Mabunda D, Mandlate F, Gonçalves-Pereira M, Xavier M, et al Reducing the number of people with dementia through primary prevention in Mozambique, Brazil, and Portugal: an analysis of populationbased data. J Alzheimers Dis 2019; 70 Suppl 1:S283-91.

15. Hoang TD, Reis J, Zhu N, Jacobs Jr. DR, Launer LJ, Whitmer RA, et al. Effect of early adult patterns of physical activity and television viewing on midlife cognitive function. JAMA Psychiatry 2016; 73:73-9.

16. Rovio S, Kåreholt I, Helkala E-L, Viitanen M, Winblad B, Tuomilehto J, et al. Leisure-time physical activity at midlife and the risk of dementia and Alzheimer's disease. Lancet Neurol 2005; 4:705-11.

17. Guthold R, Stevens GA, Riley LM, Bull FC. Worldwide trends in insufficient physical activity from 2001 to 2016: a pooled analysis of 358 population-based surveys with 1.9 million participants. Lancet Glob Heath 2018 6:e1077-86. 
18. World Health Organization. Global recommendations on physical activity for health. Geneva: World Health Organization; 2010.

19. McPhee JS, French DP, Jackson D, Nazroo J, Pendleton N, Degens H. Physical activity in older age: perspectives for healthy ageing and frailty. Biogerontology 2016; 17:567-80.

20. Gebel K, Ding D, Chey T, Stamatakis E, Brown WJ, Bauman AE. Effect of moderate to vigorous physical activity on all-cause mortality in middle-aged and older Australians. JAMA Intern Med 2015; 175:970-7.

21. Madeira MC, Siqueira FCV, Facchini LA, Silveira DS, Tomasi E, Thumé E. Atividade física no deslocamento em adultos e idosos do Brasil: prevalências e fatores associados. Cad Saúde Pública 2013; 29:165-74.

22. Bielemann RM, Silva BGC, Coll CVN, Xavier MO, Silva SG. Impacto da inatividade física e custos de hospitalização por doenças crônicas. Rev Saúde Pública 2015; 49:75.

23. Szwarcwald CL, Malta DC, Pereira CA, Vieira MLFP, Conde WL, Souza Júnior PRB, et al. Pesquisa Nacional de Saúde no Brasil: concepção e metodologia de aplicação. Ciênc Saúde Colet 2014; 19:333-42.

24. Craig CL, Marshall AL, Sjöström M, Bauman AE, Booth ML, Ainsworth BE, et al. International physical activity questionnaire: 12 -country reliability and validity. Med Sci Sport Exerc 2003; 35:1381-95.

25. Instituto Brasileiro de Geografia e Estatística. Pesquisa Nacional por Amostra de Domicílios Contínua - PNAD Contínua. Divulgação anual. Rio de Janeiro: Instituto Brasileiro de Geografia e Estatística; 2013.

26. Barnes DE, Yaffe K. The projected effect of risk factor reduction on Alzheimer's disease prevalence. Lancet Neurol 2011; 10:819-28.

27. Hamer M, Chida Y. Physical activity and risk of neurodegenerative disease: a systematic review of prospective evidence. Psychol Med 2009; 39:3-11.

28. Sichieri R, Nascimento S, Coutinho W. The burden of hospitalization due to overweight and obesity in Brazil. Cad Saúde Pública 2007; 23:1721-7.

29. Norton S, Matthews FE, Barnes DE, Yaffe K, Brayne C. Potential for primary prevention of Alzheimer's disease: an analysis of populationbased data. Lancet Neurol 2014; 13:788-94.

30. Hallal PC, Andersen LB, Bull FC, Guthold R, Haskell W, Ekelund U, et al. Global physical activity levels: surveillance progress, pitfalls, and prospects. Lancet 2012; 380:247-57.

31. Mielke MM, Vemuri P, Rocca WA. Clinical epidemiology of Alzheimer's disease: assessing sex and gender differences. Clin Epidemiol 2014; 6:37-48.

32. World Health Organization. World report on ageing and health. Geneva: World Health Organization; 2015.

33. O'Brien JT, Thomas A. Vascular dementia. Lancet 2015; 386:1698-706.
34. Ruitenberg A, Ott A, van Swieten JC, A Hofman, Breteler MM. Incidence of dementia: does gender make a difference? Neurobiol Aging 2001; 22:575-80.

35. Alladi S, Kaul S, Meena AK, Somayajula S, Umadevi M, Reddy JM. Pattern of vascular dementia in India: study of clinical features, imaging, and vascular mechanisms from a hospital dementia registry. J Stroke Cerebrovasc Dis 2006; 15:49-56.

36. Zhou DHD, Wang JYJ, Li J, Deng J, Gao C, Chen M. Frequency and risk factors of vascular cognitive impairment three months after ischemic stroke in china: the Chongqing stroke study. Neuroepidemiology 2005; 24:87-95.

37. Sabia S, Fayosse A, Dumurgier J, Schnitzler A, Empana J-P, Ebmeier KP, et al. Association of ideal cardiovascular health at age 50 with incidence of dementia: 25 year followup of Whitehall II cohort study. BMJ 2019; 366:14414.

38. Enes CC, Nucci LB. A telephone surveillance system for noncommunicable diseases in Brazil. Public Health Rep 2019; 134:324-7.

39. Mehta KM, Yeo GW. Systematic review of dementia prevalence and incidence in United States race/ethnic populations. Alzheimers Dement 2017; 13:72-83.

40. Barros MBA, Lima MG, Medina LPB, Szwarcwald CL, Malta DC. Social inequalities in health behaviors among Brazilian adults: $\mathrm{Na}$ tional Health Survey, 2013. Int J Equity Health 2016; 15:148.

41. Chiavegatto Filho ADP, Beltrán-Sánchez H, Kawachi I. Racial disparities in life expectancy in Brazil: challenges from a multiracial society. Am J Public Health 2014; 104:2156-62.

42. Livingston G, Sommerlad A, Orgeta V, Costafreda SG, Huntley J, Ames D, et al. Dementia prevention, intervention, and care. Lancet 2017; 390:2673-734.

43. Mansournia MA, Altman DG. Population attributable fraction. BMJ 2018; 360:k757.

44. Mielke GI, Malta DC, Sá GBAR, Reis RS, Hallal PC. Regional differences and correlates of leisure time physical activity in Brazil: results from the Brazilian National Health Survey-2013. Rev Bras Epidemiol 2015; 18:15869.

45. Ferreira Mendes GF, Häfele V, Blumenberg C, Werneck AO, Radicchi MR, Coll CVN, et al. Comparação das estimativas de atividade física e comportamento sedentário em adultos brasileiros no VIGITEL e PNS, Brasil, 2013. Rev Bras Ativ Fís Saúde 2018;23:e0062.

46. Al Tunaiji H, Davis JC, Mansournia MA Khan KM. Population attributable fraction of leading non-communicable cardiovascular diseases due to leisure-time physical inactivity: a systematic review. BMJ Open Sport Exerc Med 2019; 5:e00512. 


\section{Resumo}

Os autores buscaram estimar a carga econômica da inatividade física de lazer nas internações hospitalares por demência no Brasil. O estudo descritivo de abrangência nacional utilizou dados do Departamento de Informática do SUS e da última Pesquisa Nacional de Saúde (2013). A taxa de internações hospitalares e o custo econômico se referem ao ano de 2013. A prevalência de inatividade física de lazer foi usada para calcular a fração atribuível populacional de demência. Os desfechos foram estratificados por sexo (masculino/ feminino), grupo etário $(<50,50-59,60-69,70-79$, 80+), raça/cor (branco, preto, pardo, outro) e macrorregião (Sul, Sudeste, Norte, Nordeste e Centrooeste). Em 2013, 3.724 pessoas foram hospitalizadas por demência no Brasil, resultando em um custo total de $R \$ 17.971 .833,85$. Entre os homens, mais da metade do custo foi em indivíduos abaixo de 59 anos de idade, brancos e pardos e da Região Sudeste. Entre as mulheres, a proporção dos custos foi maior na faixa etária acima de 60 anos e nas pacientes brancas. Em 2013, 37\% de todas as internações hospitalares por demência no Brasil foram atribuíveis à inatividade física, chegando a 42,9\% e 43,8\% em homens e mulheres com 80 anos ou mais, respectivamente. A inatividade física custou R\$ 6.994.254,75 em 2013, em internações hospitalares por demência no Brasil. Os maiores custos atribuiveis foram identificados nos pacientes abaixo de 50 anos de idade e em mulheres acima de 80 anos. São necessárias estratégias para preservar a qualidade de vida desses pacientes, a fim de reduzir a carga da doença para pacientes, famílias e o sistema de saúde.

Demência; Exercício; Hospitalização

\section{Resumen}

El objetivo de este estudio fue determinar la carga económica de la inactividad física durante el tiempo libre en hospitalizaciones por demencia en Brasil. En este estudio descriptivo de carácter nacional, utilizamos datos secundarios procedentes del Departamento de Informática del Sistema Únido de Salud de Brasil, así como de la última Encuesta Nacional de Salud (2013). La tasa de hospitalización y coste económico se obtuvieron desde el 2013. La prevalencia de inactividad física durante el tiempo libre se utilizó para calcular el porcentaje correspondiente de población atribuible por demencia. Los resultados fueron estratificados por sexo (masculino/femenino), grupos de edad $(<50,50-59,60-69,70-79,80+)$, etnicidad (blanco, negro, mestizo, otros), y región (Sur, Sureste, Norte, Noreste, y Centro-oeste). En 2013, 3.724 personas fueron hospitalizadas debido a la demencia en Brasil, suponiendo en un coste total de BRL 17.971.833,85 (USD 7.673.973,05). Más de la mitad del coste entre hombres se gastó con personas de edad inferior a 59 años, blancos y mestizos, $y$ procedentes de la región Sureste. La proporción del coste fue mayor en mujeres mayores de 60 años $y$ blancas. Un 37\% de todas las hospitalizaciones por demencia en Brasil fueron atribuibles a la inactividad física en 2013, con valores que alcanzaban un 42,9\% para hombres y un 43,8\% para mujeres con 80 años o mayores. La inactividad física costó BRL 6.994.254,75 (USD 2.986.546,78) en 2013 en hospitalizaciones, debido a la demencia en Brasil. Se descubrió un coste más alto, atribuible a pacientes con edades inferiores a 50 años y mujeres mayores de 80. Se necesitan estrategias para preservar la calidad de vida de estos pacientes, con el fin de reducir la carga para el paciente, su familia, y para el sistema de salud.

Demencia; Ejercicio Físico; Hospitalización
Submitted on 11/Mar/2020

Final version resubmitted on 25/May/2020

Approved on 24/Jun/2020 